\title{
INTEGRASI PENDIDIKAN MADRASAH DALAM SISTEM PENDIDIKAN NASIONAL (Studi kebijakan Pendidikan Madrasah di Indonesia)
}

\author{
Yoga Anjas Pratama \\ Yogaanjasp8@gmail.com \\ UIN Sunan Kalijaga Yogyakarta
}

\begin{abstract}
Madrasah education is Islamic education that is integrated with the national education system. But in its development Islamic education experiences various problems, namely: (1) Stigma of society that considers madrasa as second class education (2) Until the left behind of madrassas from other general education. therefore in this research will be studied more deeply, about madrasah education integration in the national education system which is reviewed based on the perspective of madrasa education policy in Indonesia. This study aims to determine the integration of madrasa education in the national education system. This research is library research conducted by way of tracing books, articles, and related documents, to then be analyzed using descriptive analysis. The results and conclusions from this study are: First, madrasa education has been integrated with the national education system. Secondly, madrasa education is not second class education that lags behind other general education. Third, the government has issued various policies to advance madrasah education, as follows: (1) Madrasah education has the same rights as other general education (to get attention, assistance, equal treatment) (2) Madrasa education (MI, MTs, and MA) is equivalent to other general education, (3) Can move to other general education institutions with the same education pathways and levels, and (4) Can continue education to prestigious Islamic Higher Education, as well as other general education.
\end{abstract}

Keywords: Madrasah Education, National Education System

\begin{abstract}
Abstrak
Pendidikan madrasah merupakan pendidikan Islam yang terintegrasi dengan sistem pendidikan nasional. Tetapi dalam perkembanganya pendidikan madrasah mengalami berbagai permasalahan, yaitu: (1) Stigma masyarakat yang menganggap madrasah sebagai pendidikan kelas dua (2) Hingga tertinggalnya madrasah dari pendidikan umum lainya. Untuk itu dalam penelitian ini akan dikaji lebih mendalam mengenai integrasi pendidikan madrasah dalam sistem pendidikan nasional yang dikaji berdasarkan perspektif kebijakan pendidikan madrasah di Indonesia. Penelitian ini bertujuan untuk mengetahui integrasi pendidikan madrasah dalam sistem pendidikan nasional. Penelitian ini merupakan penelitian kepustakaan yang dilakukan dengan cara menelusuri buku-buku, artikel, dan dokumen-dokumen terkait, untuk kemudian dianalisis dengan menggunakan analisis deskriptif. Hasil dan kesimpulan dari penelitian ini ialah bahwa: Pertama, pendidikan madrasah telah terintegrasi dengan sistem pendidikan nasional. Kedua, pendidikan madrasah bukanlah pendidikan kelas dua yang tertinggal dari penidikan umum lainya. Ketiga, pemerintah telah mengeluarkan berbagai kebijakan untuk memajukan pendidikan madrasah, sebagai berikut: (1) Pendidikan madrasah mempunyai hak yang sama dengan pendidikan umum lainya (untuk mendapat perhatian, bantuan, dan perlakuan yang sama) (2) Pendidikan madrasah (MI, MTs, dan MA) setara/sederajat dengan pendidikan umum lainya, (3) Dapat pindah ke lembaga pendidikan umum lainya dengan jalur dan jenjang pendidikan yang sama, dan (4) Dapat melanjutkan pendidikan ke Pendidikan Tinggi Islam yang bergengsi, maupun pendidikan umum lainya.
\end{abstract}

Kata kunci: Pendidikan Madrasah, Sistem Pendidikan Nasional 


\section{PENDAHULUAN}

Madrasah ialah lembaga pendidikan yang lahir untuk masyarakat. Malik Fadjar mengatakan bahwa "Madrasah adalah madrasah" yang mempunyai arti bahwa madrasah tidak tergantikan oleh lembaga pendidikan lainya, hal ini dikarenakan madrasah memiliki karateristik dan visi, misi yang sangat khas di dalam masyarakat bangsa indonesia, baik itu dilihat dari segi pendidikan, kebudayaan, politik, bahkan ekonomi.(Yahya, 2014). Pada awal kemunculanya abad ke 20, madrasah merupakan lembaga pendidikan yang lahir akibat adanya proses tarik menarik antara pendidikan tradisional pesantren dengan pendidikan modern belanda, serta adanya keinginan dan tuntutan masyarakat agar anak-anak mereka memperoleh pengetahuan agama.(Shaleh, 2006). Madrasah dalam perkembanganya tidak lagi dipandang sebagai lembaga penddidikan Islam yang berfokus pada ilmu-ilmu keagamaan hal ini dikarenakan madrasah telah mengalami modernisasi sehingga dimadrasah diajarkan pula mengenai ilmu-ilmu umum lainya, seperti: Kimia, Fisika, Ilmu Sosial dan lain sebagainya.

Madrasah sebagai lembaga pendidikan mempunyai misi untuk mewujudkan citacita bangsa, yaitu: mencerdaskan dan meningkatkan keimanan serta ketakwaan dalam kehidupan berbangsa. Hal ini ditegaskan dalam UUD RI Tahun 1945 pasal 31 ayat (3) yang mengatakan bahwa pemerintah menyelenggarakan dan mengupayakan satu sistem pendidikan nasional untuk meningkatkan keimanan dan ketakwaan dan ahlak mulia dalam rangka mencerdaskan kehidupan bangsa yang diatur dalam undang-udang .(Fathoni, 2005). Selain itu berdasarkan konstitusi UUD 1945 dan UU Sisdiknas, madrasah kini telah terintegrasi dalam sistem pendidikan nasional. Amanat konstitusi UUD 1945 dan UU Sisdiknas, menyebutkan, bahwa: pentingnya pelaksanaan pendidikan dengan melestarikan keanekaragamaan pelaksanaan pendidikan di masyarakat, dalam satu payung pengelolaan yang sama yaitu: "sistem pendidikan nasional”. (Fathoni, 2005)

Berdasarkan beberapa penjelasan diatas maka dapat dipahami bahwa madrasah ialah lembaga pendidikan Islam yang terintergasi dengan sistem pendidikan nasional, yang memiliki fungsi sebagai tempat untuk memperdalam ilmu agama (tafaqquh fi aldin) sehingga dapat menjadi ahli agama, tempat menyalurkan ajaran-ajaran Islam sehingga dapat diterapkan / diamalkan dalam kehidupan bermasyarakat sehari-hari, dan tempat untuk penyiapan sumber daya manusia dalam mengisi lowongan-lowongan 
lapangan pekerjaan yang ada di masyarakat.(Malla, H., Hi., 2010). Fathul Jannah dalam penelitianya "Pendidikan Islam dalam Sistem Pendidikan Nasional" mengatakan bahwa pendidikan Islam merupakan bagian intergral dari sistem pendidikan nasional dan untuk itu legtimasi untuk dapat terus eksis dan mendapatkan hak / tempat-tempat dalam memenuhi kebutuhan pendidikan bagi masyarat Islam Indonesia diberikan kepada madrasah selaku lembaga pendidikan Islam.(Jannah, 2013)

Terintegrasinya madrasah kedalam sistem pendidikan nasional telah membawa madrasah kepada perkembangan yang pesat, seperti: adanya kebijakan madrasah MAPK, madrasah model, pemberdayaan madrasah swasta, peningkatan mutu madrasah, dana bantuan dari pemerintah dll. Namun dalam perkembanganya, madrasah masih mengalami banyak masalah seperti: (1) Stigma masyararakat yang menganggap madrasah sebagai pendidikan kelas dua (2) Hingga tertinggalnya madrasah dari pendidikan umum lainya. Permasalahan-permasalahan tersebut tentunya menjadi pekerjaan rumah bagi kita agar kedepanya dapat membimbing pendidikan madrasah kearah kemajuan. Berangkat dari permasalah diatas maka dalam penelitian ini akan penulis kaji lebih mendalam mengenai integrasi pendidikan madrasah dalam sistem pendidikan nasional (studi kebijakan pendidikan madrasah). Kajian ini dimaksudkan untuk mengetahui lebih mendalam mengenai integrasi pendidikan madrasah dalam sistem pendidikan nasional yang penulis kaji berdasarkan perspektif kebijakan pendidikan madrasah di Indonesia.

\section{METODE PENELITIAN}

Penelitian ini merupakan penelitian kepustakaan (library research) yang difokuskan pada kajian mengenai integrasi pendidikan madrasah dalam sistem pendidikan nasional, yang dikaji berdasarkan perspektif kebijakan pendidikan madrasah di Indonesia. Adapun sumber data dalam penelitian ini ialah segala bentuk sumber kepustakaan, seperti: buku-buku, artikel, majalah dan dokumen-dokumen lainya yang terkait. (Pratama, 2018). Pengumpulan data dalam penelitian ini dilakukan dengan cara penelusuran terhadap buku-buku, artikel, dan dokumen-dokumen yang terkait dengan kajian penelitian. Untuk kemudian dilakukan anlisis data dengan menggunakan metode analisis konten, yaitu dengan mereduksi, mengorgasisasi, dan memaparkan data yang diperoleh dari sumber kepustakaan guna memperoleh gambaran secara lengkap, 
melakukan verifikasi dan menyimpulkan data untuk menjawab rumusan masalah yang telah ditetapkan.

\section{HASIL KAJIAN DAN PEMBAHASAN}

\section{Sejarah Pendidikan Madrasah}

\section{Madrasah Pra Kemerdekaan}

Berkembangnya pendidikan madrasah (pendidikan Islam) di Indonesia di mulai sejak awal abad ke-20 M yang ditandai dengan didirikanya madrasah-madrasah, surau / ponpes, di pulau Kalimantan dan Sumatera. Pendidikan madrasah pada masa pra kemerdekaan didirikan atas dasar dua hal, yaitu: (1) Kurang sistematisya pendidikan Islam saat itu yang masih bersifat tradisional serta belum bisa memberikan kemampuankemampuan pragmatis yang mencukupi. (2) Lembaga-lembaga pendidikan milik Belanda saat itu berkembang dengan pesat, meluas dan membawa watak sekuler sehingga sistem pendidikan Islam yang lebih terukur, teratur, dan terncana harus segera dihadirkan untuk mengimbangi laju perkembangan pendidikan Belanda pesat dan meluas tersebut (Machali \& Hidayat, 2016).

Pada masa kolonial, pemerintah Belanda membuat sebuah kebijakan terhadap pendidikan Islam, dimana kebijakan tersebut bersifat menekan dan diskriminatif. Kebijakan tersebut adalah dengan dikeluarkanya peraturan wilde schoolen ordonatie tahun 1993 yang berakibat pada terisolasinya pendidikan Islam dari arus modernisasi (Tilar, 2000). Pengeluaran kebijakan wilde schoolen ordonatie tersebut disebabkan oleh adanya kosekuensi dari pendidikan Islam yang merugikan kepentingan Hidia Belanda. Hal ini dikarekan pendidikan Islam menanamkan nilai-nilai keimanan yang yang membangkitkan semangat untuk melawan pemerintahan kafir atau penjajahan. (Yahya, 2014). Pemberlakuan kebijakan wilde schoolen ordonatie inilah yang nantinya menjadi awal cikal bakal terlahirnya dualisme dalam sistem pendidikan di Indonesia. Dimana pendidikan Islam pada waktu itu dibiarkan tetap berjalan sesuai dengan karaternya meskipun adanya pengkontorlan dari pihak Belanda, dan pendidikan Belanda pun berkembang dan menjadi pusat pengajaran bagi orang-orang elit pribumi Belanda (Yahya, 2014). Sehingga sampai saat ini dapat kita jumpai dualisme pendidikan di Indonesia, yakni adanya pendidikan umum dan pendidikan madrasah, sebagai dampak dari dualisme pendidikan pada masa pra kemerdekaan. 
Kemudian setelah belanda meninggalkan Indonesia, kebijakan diskiriminatif pun masih dirasakan hingga masa penjajahan Jepang. Kebijakan pada masa penjajahan Jepang ini diorientasikan pada penguatan kekuasaan dan pengaruhnya di Indonesia. Dimana pemerintah Jepang saat itu memberikan bantuan untuk madrasah dan sekolah dengan tujuan agar perkembangan pendidikan Islam dapat lebih terkontrol. Selain itu pemerintah Jepang juga banyak mengangkat kalangan priyayi untuk menduduki jabatjabatan penting di Kantor Urusan Agama, hal ini dimaksudkan agar pembinaan dan pertemuan guru-guru agama saat itu dapat diorganisasikan sehingga nantinya berdampak pada pengkontrolan terhadap madrasah dan pondok pesantren. (Machali \& Hidayat, 2016).

\section{Madrasah Pasca Kemerdekaan}

Masa orde lama. Pada masa orde lama telah berkembang dualisme pendidikan di Indoensia, yaitu: pendidikan umum dan pendidikan Islam / madrasah. Pendidikan Islam pada masa ini dikelola oleh Departemen Agama dan telah diakui, dilindungi, serta dikembangkan oleh pemerintah. Hal ini dijelaskan dalam UUD 1945, Pasal 31 ayat (2) yang mengatakan bahwa, pemerintah menyelenggarakan dan mengupayakan satu sistem pengajaran nasional, yang diatur oleh undang-undang (Machali \& Hidayat, 2016). Dengan begitu maka secara tidak langsung penyelenggaraan pendidikan Islam di Indonesia ialah bagian dari subsistem pendidikan nasional"(Machali \& Hidayat, 2016). Kemudian pada tanggal 22 Desember 1945 dalam rapatnya BP-KNIP memberikan putusan bahwa untuk memajukan pengajaran dan pendidikan di Indonesia maka pendidikan di madrasah dan dilanggar diputuskan agar terus berjalan dan dicepat. (Machali \& Hidayat, 2016).

Keputusan ini diikuti dengan dikeluarkanya putusan BKNIP yang isinya, yaitu: madrasah dan pesantren pada dasarnya ialah salah satu alat pencerdasaana bangsa yang harus mendapatkan perhatian dan bantuan yang nyata dari pemerintah (materil). (Hasbullah, 2015). Kuatnya dukungan dari pemerintah ini membuat madrasah-madrasah di Indonesia mengalami perkembangan dengan pesatnya, sehingga pada pertengahan tahun 1960-an terdapat 13.057 Madrasah Ibtidaiyah (MI) dengan 1.927.777 siswa yang mendaftarkan diri di MI. Selanjutnya pada Madrasah Tsanawiyah (MTs) terdapat 776 madrasah dengan 87.932 siswa. Sedangkan di tingkat Madrasah Aliyah (MA) terdapat 16 madrasah dengan 1.881 siswa. Kemudian pada tahun 1966 pemerintah memberikan 
izin kepada sejumlah madrasah swasta beralih status menjadi madrasah negeri, dengan jumlah 123 MI, 182 MTs, dan 42 MA (Ismail, 2010).

Masa orde baru. Pada masa orde baru tahun 1972, Presiden Suharto mengeluarkan Keputusan Presiden (KEPPRES) No. 34 Tahun 1972 dan Instruksi Presiden (INPRES) No. 15 Tahun 1974 yang mengatur agar madrasah dikelola oleh Menteri Pendidikan dan Kebudayaan (Mendikbud), dimana sebelumnya madrasah dikelola oleh Menteri Agama. Kebijakan ini pun menuai reaksi dari masyarakat Islam yang mendorong keluarnya SKB 3 Menteri yang berisi bahwa mata pelajaran di madrasah dibina dan dilakukan oleh Menteri Agama, kemudian untuk pegawai dan pengawasan mutu mata pelajaran umum di madrasah dibina dan dilakukan oleh Menteri Pendidikan dan Kebudayaan, bersama dengan Menteri Agama dan Menteri Dalam Negeri(Natta, 2012).

Adapun tujuan dikeluarkanya SKB 3 Menteri ialah untuk peningkatan mutu madasah, yaitu: agar mata pelajaran umum dari madrasah mendapat tempat setingkat/sama dengan mata pelajaran umum dari sekolah umum lainya (Nursikin, 2018). Madrasah pada perkembangan selanjutnya telah mendapat pengakuan dari pemerintah sebagai lembaga pendidikan umum yang bercirikan Islam hal ini dikarenakan madrasah telah masuk kedalam sistem pendidikan nasional, yaitu dengan dikeluarkanya UUSPN No.2 Tahun 1989. Undang-undang Sistem Pendidikan Nasional (UUSPN) No. 2 Tahun 1989 mengamanatkan, bahwa: adanya pendidikan nasional memiliki tujuan untuk mencerdaskan kehidupan bangsa dan mengembangkan manusia Indonesia menjadi manusia seutuhnya yang trampil, berpengetahuan, berbudi pekerti, beriman, bertakwa, sehat jasmani dan rohani, berkepribadian mantap, mandiri, dan mempunyai rasa tanggung jawab terhadap masyarakat dan bangsa.

Pada BAB IV, Undang Undang Sistem Pendidikan Nasional No. 2 Tahun 1989, pasal 11 ayat (1) dan (6) disebutkan bahwa jenis pendidikan yang termasuk dalam jalur pendidikan sekolah, sebagai berikut: pendidikan umum, pendidikan luar biasa, pendidikan kejuruan, pendidikan keagamaan, pendidikan akademik pendidikan kedinasan, dan pendidikan profesional. Ayat (6) pendidikan keagamaan ialah pendidikan yang berupaya menyiapkan peserta didik untuk dapat melaksanakan peranananya yaitu dengan menguasai pengetahuan khusus tentang ajaran keagamaan. 
Kemudian pada BAB XV pasal 49 dan 50 disebutkan bahwa pelaksanaan dan pengelolaan sistem pendidikan nasional berada dalam tanggung jawab Menteri. Sedangkan pelaksanaan dan pengelolaan satuan kegiatan pendidikan dilakukan oleh Menteri-menteri dan Pimpinan Lembaga Pemerintah lainya bersangkutan. Dengan demikian dapat dipahami bahwa proses penyelenggaraan dan pengelolaan pendidikan madrasah dilakukan oleh pemerintah dan Menteri Agama yang bekerjasama dengan meteri-menteri lainya. Dikutip dari Imam Machali \& Ara Hidayat dalam The Handbook Of Management: Teori dan Praktik Pengelolaan Sekolah/Madrasah di Indonesia, disebutkan bahwa pendidikan madrasah pada masa orde baru telah terintegrasi dalam sistem pendidikan nasional, hal ini dapat dilihat dari beberapa hal, yaitu: (1) Pendidikan agama dijadikan sebagai salah satu muatan wajib dalam setiap jenis dan jalur pendidikan (2) Madrasah dalam sistem pendidikan nasional masuk dalam kategori pendidikan jalur sekolah (3) Akan tetapi meskipun madrasah masuk dalam pendidikan jalur sekolah, madrasah tetap pendidikan jenis keagamaan yang memiliki jurusan khusus ilmu-ilmu syariah(Machali \& Hidayat, 2016).

Masa reformasi. Pada masa reformasi ini diberlakukanya UU No. 20 Tahun 2003 tentang Sistem Pendidikan Nasional. UU No. 20 Tahun 2003 ini merupakan pengganti dari UU sebelumnya, yakni UUSPN No. 2 Tahun 1989 yang menurut banyak kalangan sudah tidak sesuai lagi dengan UU No. 22 Tahun 1999 tentang Otonomi Daerah (Machali \& Hidayat, 2016). UUSPN No. 20 Tahun 2003 menegaskan bahwa pendidikan merupakan suatu usaha sadar dan terencana dalam mewujudkan suasana belajar dan proses pembelajaran sehingga peserta didik dapat dengan luwes dan aktif berinteraksi serta mengembangkan potensi dirinya untuk memiliki kekuatan spritual keagamaan, kepribadian, pengendalian diri, ahlak mulia, kecerdasan, serta keterampilan yang diperlukan dirinya, masyarakat, bangsa, dan negara (Helmawati, 2013).

Pada BAB VI, UUSPN No. 20 Tahun 2003, pasal 14, 15, dan 16 disebutkan bahwa Pendidikan formal memiliki jenjang yang terdiri dari pendidikan dasar, pendidikan menengah, dan pendidikan tinggi (15) Kemudian untuk jenis pendidikannya terdiri dari pendidikan umum, kejuruan, profesi, akademik, keagamaan, vokasi, dan khusus (16) Sedangkan untuk jenjang, jalur, dan jenis pendidikan terwujud dalam bentuk satuan pendidikan yang diselenggarakan oleh pemerintah, pemerintah daerah, dan/atau masyarakat. 
Kemudian pada pasal 17 ayat (2), UUSPN No. 20 Tahun 2003 disebutkan bahwa dalam bentuknya pendidikan dasar terdiri dari sekolah dasar (SD) dan madrasah ibtidaiyah (MI) atau bentuk lain yang sederajat, kemudian untuk sekolah menengah pertama tediri dari (SMP) dan madrasah tsanawiyah (MTs), atau bentuk lain yang sederajat. Selanjutnya pada pasal 18 ayat (3) tentang pendidikan menengah disebutkan bahwa dalam bentuknya pendidikan menengah atas terdiri dari (SMA), sekolah menengah kejuruan (SMK), madrasah aliyah (MA), dan madrasah aliyah kejuruan (MAK), atau bentuk lain yang sederajat. Selanjutnya untuk memperjelas UUSPN No. 20 Tahun 2003 dikeluarkanlah PP No. 55 Tahun 2007 tentang Pendidikan Agama dan Keagamaan sebagai panduan teknis dalam mengatur pelaksanaan pendidikan agama dan keagamaan.(Machali \& Hidayat, 2016). Dari pemaparan diatas dapat dipahami bahwa pendidikan madrasah pada masa reformasi ini telah terintegrasi dengan sistem pendidikan nasional, pendidikan madrasah (MI, MTs, MA) mendapat tempat sederajat/setara dengan pendidikan umum lainya (SD, SMP, SMA, SMK dll), dan semakin diakui oleh pemerintah sebagai lembaga pendidikan umum yang bercirikan Islam.

\section{Kebijakan Pendidikan Madrasah di Indonesia}

Kebijakan merupakan sebuah keputusan pemerintah yang bersifat umum dan berlaku bagi seluruh anggota masyarakat. Kebijakan tersebut dapat berupa: UU, PP, Permen, Keppres, dll yang bersifat mengikat dan wajib dilaksanakan.(Machali \& Hidayat, 2016). Kebijakan pendidikan madrasah merupakan keputusan pemerintah yang bersifat mengikat mengenai pendidikan madrasah tentang pengaturan, pengelolaan dll, yang diwujudkan dalam bentuk program-program, UU, PP, Permen, Keppres dll. Berikut penjelasan mengenai kebijakan pendidikan madrasah di Indonesia:

1. Kebijakan awal (integrasi dalam sisdiknas dan wajib belajar).

Kebijakan awal ini dimulai sejak didirikanya madrasah pada tanggal 22 Desember 1945. Ketika itu BP-KNIP membuat maklumat yang mengharuskan pemajuan pengajaran dan pendidikan di tingkat, madrasah, pondok pesantren, pengajian-pengajian dan lain sebagainya. Maklumat ini kemudian terwujud melalui pembentukan Departemen Agama pada tanggal 3 Januari 1946. Sejak saat itu segala bentuk binaan, pengaturan dan pengembangan madrasah serta pondok pesantren menjadi tugas utama pemerintah, yaitu: oleh Departemen Agama RI (Djamas, 2005). 
Kebijakan awal ini dapat dilihat dari masa awal pemerintahan orde baru. Dimana pendekatan legal formal pada waktu itu tidak dapat memberikan dukungan terhadap pendidikan madrasah. Kemudian pada tahun 1972 Presiden Soeharto mengeluarkan Kepres No. 34 Tahun 1972 dan Inpres No. 15 Tahun 1974 yang mengatur madrasah untuk dikelola oleh Menteri Pendidikan dan Kebudayaan (Mendikbud), dengan tujuan agar dapat mendongkrak peningkatan mutu pendidikan madrasah. Akan tetapi dalam hal ini kalangan Islam pendukung sistem pendidikan Islam yang tergabung dalam Manjelis Pertimbangan dan Pemberdayaan Pendidikan Agama dan Keagamaan (MP3A) merasa keberatan, sebab keputusan tersebut dianggap sebagai upaya dari kelompok sekuler untuk mengurangi fungsi pendidikan Islam.(Djamas, 2005)

Selain itu munculnya berbagai macam permasalahan pada masa itu, semakin menambah citra keterpurukan pendidikan madrasah. Permasalahan-permasalahan tersebut, sebagai berikut: (1) Kalangan umat Islam tradisional dan konservatif mendominasi pendidikan madrasah, selain itu mereka cenderung memahami Islam sebagai agama semata tanpa memperhatikan / mengindahkan perkembangan zama, teknologi dan lain sebagainya (2) Belum masuknya pendidikan madrasah kedalam sistem pendidikan nasional (3) Pendidikan madrasah belum memiliki visi, misi dan tujuan yang jelas.(Natta, 2012). Kemudian tahun 1975, citra ketertinggalan pendidikan madrasah ini mulai membaik. Hal ini dengan dikeluarkanya SKB 3 Menteri sebagai respon dari tanggapan MP3A tentang upaya kelompok sekuler untuk mengurangi fungsi pendidikan Islam. Isi dari SKB 3 Menteri tersebut ialah untuk memberikan kembali status pengelolaan madrasah ke tangan Menteri Agama, tetapi dengan unsur kurikulum umum yang telah ditetapkan oleh pemerintah.(Ismail, 2010). Sebagai dampak positif dari adanya SKB 3 Menteri tersebut, kini madrasah diakui sebagai lembaga pendidikan formal yang memuat mata pelajaran agama sebanyak $30 \%$ dan mata pelajaran umum sebanyak 70\%. Dan MI dianggap sederajat dengan SD, kemudian MTs dianggap setara dengan SMP, dan MA dianggap setingkat dengan (SMA).(Natta, 2012)

2. Kebijakan kurikulum agama dan umum di madrasah.

Lahirnya madrasah di Indonesia disebabkan oleh adanya hubungan tarik menarik antara pendidikan tradisonal yang mengajarkan pengetahuan agama dengan pendidikan modern yang mengajarkan pengetahuan umum. Berdasarkan hal ini maka dibentuklah sistem pendidikan yang memberikan pengajaran ilmu umum dan agama, 
yang saat ini disebut dengan madrasah. Madrasah pada tahun 1958 mempunyai kurikulum yang terdiri dari $30 \%$ mata pelajaran umum dan $70 \%$ mata pelajaran agama. Hal ini sejalan dengan keputusan Departemen Agama yang pada waktu itu memperkenalkan program MWB (madrasah wajib belajar).

Kebijakan ini pun membawa citra negatif bagi madrasah karena hanya mengajarkan pelajaran umum sebanyak 30\% sehingga madrasah dianggap sebagai lembaga pendidikan yang ketinggalan zaman. Untuk memperbaiki citra keterbelakangan / ketertinggalan ini maka pada tahun 1975 dikeluarkanlah SKB 3 Menteri yang memberi ketetapan tentang kebijakan peningkatan mutu madrasah dan lulusan madrasah yang dapat melanjutkan pendidikan kejenjang pendidikan umum lainya. Selain itu untuk ijazah lulusan madrasah telah memiliki nilai yang sama dengan ijazah sekolah umum lainya, lulusan madrasah dapat melanjutkan kesekolah umum yang setingkat lebih atas, siswa madrasah dapat berpindah ke sekolah umum lainnya yang memiliki tingkat yang sama,(Daulay \& Putra, 2004) lulusan madrasah aliyah dapat melanjutkan ke perguruan tinggi baik umum maupun agama, kurikulum madrasah aliyah memiliki dua jenis program pilihan, yaitu: pilihan A (ilmu fisika, biologi, sosial dan budaya) dan pilihan B (belum dikembangkan) .(Supani, 2009)

Dalam keputusan itu dijelaskan juga tentang pengelolaan dan pembinaan mata pelajaran madrasah yang dalam hal ini diserahkan kepada Menteri Agama, dan untuk pengawasan mutu mata pelajaran umum dan pengawasan para pegawai diserahkan kepada Menteri Pendidikan dan Kebudayaan, bersama dengan Menteri Agama dan Menteri Dalam Negeri. Dan dampak positif dari adanya SKB 3 Menteri ini ialah diberlakukanya kurikulum pendidikan madrasah yang mengajarkan 30\% mata pelajaran agama dan $70 \%$ mata pelajaran umum, serta tamatan madrasah aliyah (MA) dapat melanjutkan studi ke Perguruan Tinggi Umum yang bergengsi.(Natta, 2012)

3. Kebijakan Peningkatan Mutu Madrasah

Kebijakan peningkatan mutu madrasah dapat dibagi menjadi empat kategori, yaitu: MAPK, madrasah swasta, pemberdayaan madrasah swasta, dan madmrasah terbuka. Berikut penjelasanya:

a. Madrasah Aliyah Program Khusus (MAPK).

Madrasah Aliyah Program Khusus (MAPK) merupakan madrasah yang memberikan penekanan pada ilmu-ilmu keislaman yaitu dengan memakai 
pengantar bahasa asing (Inggris dan Arab)(Natta, 2012). MAPK pertama kali didirkan pada masa Munawir Sjadali dengan tujuan agar lulusan madrasah dapat masuk / lolos di perguruan tinggi Islam yang unggul. MAPK ini dalam kurikulum pembelajaranya memuat $70 \%$ mata pelajaran agama dan $30 \%$ mata pelajaran umum (Natta, 2012). MAPK dalam perkembanganya di Indonesia telah dianggap berhasil, hal ini dibuktikan dengan temuan Munawir Sjadali tahun 1992, yaitu adanya lulusan MAPK sebanyak 40 orang yang diterima di Al-Azhar tanpa dilakukanya tes. Kemudian pada masa Tarmizi Taher sebagai Menteri Agama, diubalah MAPK menjadi Madrasah Aliyah Keagamaan (MAK) yang bersifat permanen (Natta, 2012). MAK pada masa selanjutnya mengalami kemunduruan dan semakin tersingkirkan, hal ini alah satunya dikarenakan MAK tidak terdapat dalam nomenklatur UU Sisdiknas 1989 dan 2003, hingga pada akhirnya dibeberapa tahun yang lalu Departemen Agama secara resmi menghapuskan MAK dan mengubahnya menjadi sebuah jurusan pada sistem MA (Madrasah Aliyah) yang umumnya telah banyak didominasi oleh jurusan-jurusan umum .(Umam, 2012)

b. Madrasah model

Madrasah model merupakan lembaga pendidikan percontohan yang dibentuk dan dikembangkan oleh Departemen Agama. Pembentukan madrasah model ini dilatar belakangi oleh beberapa hal, sebagai berikut: (1) Sangat memprihatinkanya mutu pendidikan madrasah di Indoensia sehingga diperlukanya madrasah percontohan yang memiliki keunggulan-keunggulan (2) Sekolah-sekolah umum relatif lebih unggul diberbagai bidang dibandingkan dengan madrasah (3) Terdapatnya berbagai keterbatasan (khususnya dana) yang mempersulit madrasah negeri dan swasta untuk melakukan perubahan secara serentak menuju sekolah dengan mutu standar.(Ismail, 2010)

Madrasah model sebagai madrasah percontohan memiliki beberapa keistimewaan yang lebih dibanding madrasah pada umumnya. Keistimewaan tersebut, sebagai berikut: (1) Memiliki fasilitas belajar yang lengkap / mewah (2) Kurikulum plus (3) Laboratorium yang elite dalam membantu proses pembelajaran saintly dan bahasa asing (4) Mempunyai perpustakaan yang lengkap dalam menyokong pengembangan bahan ajar dan medorong anak dalam memahami konsep-konsep yang diajarkan (5) Guru-guru di madrasah ini diseleksi berdasarkan 
distintive competencies (6) Siswa-siswa yang ada ialah merupakan anak-anak pilihan berdasarkan prestasi dan jenjang pendidikan sebelumnya (7) Waktu pembelajaran yang relatif lebih lama dari madrasah pada umumnya (8) Biaya sekolah cukup tinggi (9) Dapat memberikan kesejahteraan yang baik kepada para guru dan staf sehingga guru-guru dan staf betah belajar disekolah tersebut (10) Menggunakan model asrama (Natta, 2012).

c. Pemberdayaan Madrasah Swasta

Madrasah swasta di Indonesia memiliki jumlah mencapai $80 \%$ dan dari jumlah keseluruhan hanya 20\% madrasah yang mempunyai status negeri yang disubsidi dan mendapatkan perhatian penuh dari pemerintah. Madrasah swasta pada umumnya banyak didirikan oleh masyarakat dengan modal semangat keagamaan yang tinggi dengan maksud agar dapat memberikan bekal kepada generasi muslim dengan pengetahuan umum dan agama yang mencukupi (Ismail, 2010). Tetapi modal semangat keagamaan tidak lah cukup jika tidak di imbangi dengan finansial, manajemen, mutu pendidik dan sarana pendidikan yang baik., sehingga tak jarang dipedesaan ditemukan madrasah swasta dengan kondisi yang memprihatinkan.

Secara formal pemberdayaan madrasah swasta dilatar belakangi oleh adanya lokakarya pengembangan madrasah swasta dalam lingkungan organisasi pendidikan Islam yang diselenggarakan di Jakarta tanggal 19-20 November 1996 oleh Ditbinrua. Hasil dari pemberdayaan tersebut ialah meliputi beberapa aspek, seperti: manajemen, pelibatan masyarakat proses pembelajaran, dan lain sebagainya (Swasta, 1997). Pemberdayaan madrasah swasta pada awalnya hanya lah berupa bantuan-bantuan insidentil. Tetapi sejak tahun 2000 pemerintah mulai menggiatkan program tersebut yaitu dengan banyaknya bantuan dari pemerintah terhadap madrasah swasta berupa bantuan operasional madrasah (BOM), pembangunan sarana fisik, hingga bantuan-bantuan beasiswa bagi guru-guru untuk bisa melanjutkan pendidikan mereka ke jenjang S1 di Lembaga LPTK yang telah ditunjuk pemerintah PTU atau PTAIN dan lain sebagainya (Ismail, 2010).

Dari pemaparan diatas dapat dipahami bahwa pemerintah telah berusaha sebaik mungkin untuk memberdayakan madrasah swasta, yaitu dengan memberikan berbagai macam bantuan di sektor-sektor tertentu demi tercapainya pendidikan yang diharapkan dan terwujudnya cita-cita bangsa. 
d. Madrasah Terbuka

Madrasah terbuka pada mulanya didirkan atas dasar ide dari Forum Kajian Pembinaan Tenaga Teknis Peguruan Tinggi Islam (Pergurais) yang diadakan di Jakarta tanggal 5 Febuari 1996 (Terbuka, 1997). Direktur Pembinaan Kelembagaan Islam (Binbagais) Husni Rahim menegaskan tentang agenda pengembangan madrasah yang berupa rencana pembukaan madrasah terbuka di tingkat Tsanawiyah. Hal ini kemudian diwujudkan dengan dibukanya MTs terbuka oleh Tarmizi Taher (Menteri Agama RI) tanggal 16 Juli 1996 di Ponpes Nurul Qur'an, Purwasari, Sayung, Demak Jawa Tengah, sebagai upaya dalam menyikapi kebijakan UU Sisdiknas dan program wajib belajar 9 tahun (Terbuka, 1997).

Madrasah terbuka didirikan dengan tujuan agar masyarakat Indonesia memiliki kesempatan yang sama untuk dapat melanjutkan pendidikanya, khusunya bagi mereka yang mempunyai kekurangan dalam hal ekonomi atau berada didaerah pelosok dan tertinggal, sehingga dengan didirkanya madrasah terbuka ini dapat memberikan harapan akan kesetaraan bagi masyarakat dalam hal bidang pendidikan (Terbuka, 1997). Madrasah terbuka dalam penyelenggaraanya memiliki beberapa persamaan dan perbedaan dengan madrasah pada umumnya. Persamaan dan perbedaan tersebut, sebagai berikut: (1) 100\% memiliki kurikulum yang sama dengan madrasah pada umumnya hanya saja memiliki perbedaan pada segi metode pembelajaran (2) Siswa lebih ditekankan pada aspek kemandirian belajar, oleh karena itu bahan ajar yang digunakan pun banyak yang berbentuk modul, yang ditunjang dengan media-media pembelajaran lainya, seperti: gambar, radio dll.

\section{Sistem Pendidikan Nasional}

Sistem pendidikan nasional merupakan serangkaian penyelenggaraan kegiatan pendidikan yang bertaraf nasional yang didalamnya terdapat komponen-komponen yang mendukung ketercapaian tujuan pendidikan nasional. Pasal 1 UU RI No. 20 Tahun 2003 mengartikan bahwa sistem pendidikan nasional merupakan keseluruhan komponen pendidikan yang saling terkait secara terpadu untuk mencapai tujuan pendidikan nasional (Munirah, 2015).

Sistem pendidikan nasional didasari oleh Pancasila dan UUD 1945 yang diatur dalam UU Sisdiknas No. 2 Tahun 1989 yang kemudian diganti dengan UU Sisdiknas No. 20 Tahun 2003. UU Sisdiknas No. 20 Tahun 2003 mengamanatkan bahwa 
pendidikan merupakan upaya terencana dalam mewujudkan proses dan suasana pembelajaran agar dengan sendirinya peserta didik dapat secara aktif dan luwes dalam mengembangkan potensi-potensi yang dimiliki, sehingga peserta didik tersebut dapat menguasai dan memiliki kekuatan spritual keagamaan, kecerdasan, kepribadian, ahlak mulia, serta keterampilan yang diperlukan bagai dirinya, masyarakat, bangsa, dan negara.

Sistem pendidikan nasional sudah mulai dibangun sejak tahun 1945, dengan maksud untuk memberikan pendidikan bagi putra, putri bangsa dalam rangka mencerdaskan kehidupan bangsa dan membantu tercapainya tujuan nasional, serta melestarikan budaya dan keragamaan Indonesia. UUD RI 1945 Pasal 31 ayat (3) mengamanatkan bahwa pemerintah mengupayakan dan melaksanakan satu sistem pendidikan nasional yang dapat meningkatkan keimanaan dan ketakwaan serta akhlak mulia dengan maksud untuk mencerdaskan kehidupan bangsa beradasarkan undangundang"(Fathoni, 2005). Pendidikan yang baik adalah pendidikan yang dapat memanfaatkan potensi budaya dan keberagaman (ragam suku, agama, adat istiadat dll) di Indonesia. Berangkat dari hal ini maka konstitusi UUD 1945 dan UU Sisdiknas mengamatkan pentingnya melaksanakan / menyelenggarakan pendidikan dengan melestarikan keanekaragamaan penyelenggaran pendidikan di masyarakat dalam satu payung pengelolaan, yaitu: "sistem pendidikan nasional" (Fathoni, 2005).

Keanekaragamaan penyelenggaran pendidikan di Indonesia dapat dibagi menjadi dua kategori, sebagai berikut: (1) Keragamaan yang dimiliki masyarakat dengan tingkat kreatifitas yang rendah. Masyarakat seperti ini lebih memilih keseragamaan karena dianggap memudahkan. Keseragamaan ini berbentuk nomenklatur seperti: seragam sekolah, sistem penilaian, hari masuk dan libur sekolah dll (2) Keragamaan yang dimiliki oleh masyarakat dengan tingkat kreatif yang cukup tinggi. Masyarakat seperti ini mengatakan pemerintah banyak ambil tangan (mengatur) hingga pada hal-hal yang sebenarnya tidak mesti diatur, seperti: sekolah-sekolah swasta yang memiliki tingkat kemandirian yang tinggi, yang hanya menginginkan pemerintah mengukur hasil pendidikan nya saja, sedangkan untuk proses penyelenggaraan pendidikanya tidak perlu diatur, hal ini dikarenakan yang terpenting adalah mutu keluaran yang dapat dipertanggung jawabkan (Fathoni, 2005). 
Tingginya tingkat keankeragamaan penyelenggaraan pendidikan ini mendorong pemerintah untuk membuat sebuah penyeragamaan pendidikan yang disebut dengan Standarisasi Nasional Pendidikan (SNP). Hadirnya SNP dalam penyelenggaran pendidikan bertujuan untuk (1) Menghasilkan pendidikan yang bermutu dan berdaya saing (2) Mempertemukan tradisi pendidikan yang berkembang di masyarakat secara liar dengan kebijakan negara melalui deal-deal yang bisa disepakati (3) Pelestarian keragaman diantara lembaga pendidikan agar dapat saling bersinergi dan saling melengkapi (Fathoni, 2005). SNP dalam perkembanganya kemudian melahirkan BSNP

(Badan Standar Nasional Pendidikan) yang mengatur mengenai standarisasi pendidikan. Aturan standarisasi pendidikan ini dijelaskan dalam PP Nomor 19 Tahun 2004, yang mengatur bahwa semua jenis pendidikan yang selama ini tidak diakui persamaanya dengan pendidikan umum formal, dapat diakui sepanjang persyaratan standar minimal dipenuhi (Fathoni, 2005). Akbitanya satu persatu pendidikan tradisional (pondok pesantren, pendidikan Islam lainya) kini memiliki hak yang tidak jauh beda dengan sekolah umum lainya. Dan lembaga pendidikan yang telah memenuhi standarisasi nasional pendidikan (SNP), dan kualifikasi tertentu dapat terintegrasi dalam sistem pendidikan nasional.

\section{Integrasi Pendidikan Madrasah dalam Sistem Pendidikan Nasional}

Sistem pendidikan nasional merupakan serangkaian kegiatan pelaksanaan dan penyelenggaraan pendidikan bertaraf nasional yang didalamnya terdapat komponenkompenen yang dilibatkan dalam rangka pencapaian tujuan pendidikan nasional (Rahman, 2008). Madrasah merupakan lembaga pendidikan Islam yang telah terintegrasi dalam sistem pendidikan nasional. UU Sisdiknas No. 2 Tahun 1989 menegaskan bahwa pelaksanaan atau penyelenggaraan pendidikan agama ialah merupakan bagian yang tidak dapat dipisahkan dari sistem pendidikan nasional(Ismail, 2010). Selain itu Peraturan Pemerintah (PP) No. 28 Tahun 1990 tentang Pendidikan Dasar dan PP No. 29 Tahun 1990 tentang Pendidikan Menengah mengeaskan bahwa madrasah merupakan lembaga pendidikan yang diatur dan berada dalam subsitem pendidikan nasional (Hasbullah, 2015).

UU Sisdiknas No. 20 Tahun 2003 mengamanatkan bahwa pendidikan nasional berfungsi untuk pengembangan kemampuan dan pembentukan watak dan peradaban bangsa yang bermartabat dengan maksud untuk mencerdaskan kehidupan bangsa, dan 
menjadikan peserta didik sebagai manusia yang berpotensi, beriman, bertakwa, sehat, berakhlak mulia, berilmu, mandiri, kreatif, cakap dan dapat menjadi warga negara yang bertanggung jawab dan demokratis (Ismail, 2010). Kemudian dalam pasal 17 ayat (2) dan 18 ayat (3) UU Sisdiknas No. 20 Tahun 2003 dijelaskan, bahwa pendidikan madrasah, yaitu: MI, MTs, MA mempunyai posisi dan hak yang sama dengan sekolah / pendidikan umum lainya (Ismail, 2010). Berikut isi pasal 17 ayat (2), bahwa pendidikan dasar seperti SD dan MI atau bentuk lain yang sederajat serta SMP dan MTs atau bentuk lain sederajat. Pasal 18 ayat (3), bahwa pendidikan menengah berbentuk sekolah SMA, MA, SMK, dan MAK, atau bentuk lain yang sederajat (Machali \& Hidayat, 2016).

Dari beberapa pemaparan diatas dapat disimpulkan bahwa, madrasah bukanlah lembaga pendidikan kelas dua yang tertinggal jauh dari pendidikan umum lainya. Madrasah merupakan lembaga pendidikan Islam yang telah terintegrasi dengan sistem pendidikan nasional. Hal ini dikarenakan pendidikan madrasah memiliki tujuan yang sama dengan sistem pendidikan nasional, yaitu: menjadikan anak-anak didik menjadi manusia yang memiliki keimanan, kecerdasan, ketakwaan, berilmu, berbudi luhur dan pekerti, sehat jasmani dan rohani, terampil, mandiri, berkepribadian yang baik, dan tentunya cinta terhadap tanah air (Malla, H., Hi., 2010). Untuk itu pendidikan madrasah mempunyai hak yang sama (mendapat perhatian, bantuan, dan perlakuan) dengan pendidikan umum lainya. Sehingga tidak ada pembeda antara pendidikan madrasah dengan pendidikan umum lainnya terkait hak dan kewajibannya.

\section{SIMPULAN DAN SARAN}

Pendidikan madrasah merupakan pendidikan Islam yang telah terintegrasi dengan sistem pendidikan nasional dan bukanlah pendidikan kelas dua yang tertinggal dari penidikan umum lainya. Pemerintah dalam memajukan pendidikan madrasah mengeluarkan beberapa kebijakan, yaitu: (1) Kebijakan awal (integrasi dalam sisdiknas dan wajib belajar) (2) Kebijakan kurikulum agama dan umum di madrasah (3) Kebijakan peningkatan mutu madrasah (madrasah MAPK, madrasah model, pemberdayaan madrasah swasta, dan madrasah terbuka). Dari kebijakan-kebijakan tersebut maka pendidikan madrasah bukanlah pendidikan kelas dua yang tertinggal dari pendidikan umum lainya, dan pendidikan madrasah mempunyai hak yang sama dengan 
pendidikan umum lainya, yaitu: untuk mendapat perhatian, bantuan, dan perlakuan yang sama. Hal ini ditegaskan dalam UU Sisdiknas No. 2 Tahun 1989, dan UU Sisdiknas No. 20 Tahun 2003, bahwa pendidikan madrasah merupakan bagian dari sistem pendidikan nasional, lembaga pendidikan madrasah (MI, MTs, dan MA) setara/sederajat dengan pendidikan umum lainya, mempunyai hak untuk pindah ke lembaga pendidikan umum lainya dengan jalur dan jenjang pendidikan yang sama, dan dapat melanjutkan pendidikan ke Pendidikan Tinggi Islam yang bergengsi, maupun pendidikan umum lainya. Untuk itu kedepanya diharapkan dari segala aspek (kebijakan, pemerintah, masyarakat dll) dapat terus mendukung dan membimbing pendidikan madrasah kearah kemajuan.

\section{DAFTAR PUSTAKA}

Daulay, \& Putra. (2004). Pendidikan Islam Dalam Sistem Pendidikan Nasional Di Indonesia. Jakarta: kencana.

Djamas. (2005). Posisi Madrasah di Tengah Perubahan Sistem Pendidikan Islam. Jurnal Edukasi, 3,

Fathoni, M. . (2005). Pendidikan Islam dan Pendidikan Nasional: Paradigma Baru. Jakarta: Departemen Agama RI: Direktorat Kelembagaan Agama Islam.

Hasbullah. (2015). Kebijakan Pendidikan: Dalam Perspektif Teori, Aplikasi, dan Kondisi Objektif Pendidikan di Indonesia. Jakarta.: PT Raja grafindo Persada.

Helmawati. (2013). Pendidikan Nasional dan Optimalisasi Majelis Ta'lim: Peran Aktif Majelis Ta'lim Meningkatkan Mutu Pendidikan. Jakarta: PT Rineka Cipta.

Ismail. (2010). Politik Pendidikan Madrasah di Indonesia Pasca Kemerdekaan. Jurnal Ta'bid, 2,

Jannah, F. (2013). Pendidikan Islam dalam Sistem Pendidikan Nasional. Jurnal Dinamika Ilmu, 13,

Machali, \& Hidayat. (2016). Teori dan Praktik Pengelolaan Sekolah / Madrasah di Indonesia. Jakarta.: Prenada Media Grup.

Malla, H., Hi., A. A. (2010). Madrasah dalam Sistem Pendidikan Nasional. Jurnal Inspirasi, 1 ,

Munirah. (2015). Sistem Pendidikan di Indonesia: Antara Keinginan dan Realita. Jurnal Auladuna, 2, 
Natta. (2012). Mengatasi Kelemahan Pendidikan Islam di Indonesia. Jakarta: Kencana Prenada Media Group.

Nursikin. (2018). Eksitensi Madrasah dan Sekolah Islam sebagai Lembaga Pendidikan Islam dalam Sistem Pendidikan Nasional (Studi Kasus di MAN Yogyakarta III dan SMA Muhammadiyah 1 Yogyakarta). Jurnal Istawa, 1,

Pratama. (2018). Relavansi Teori Belajar Behaviorisme Terhadap Pendidikan Agama Islam. Jurnal Pendidikan Agama Islam Al-Thariqah, 4,

Rahman. (2008). Memahami Pendidikan dan Ilmu Pendidikan. Yogyakarta: CV. Aswaja Pressindo.

Shaleh, A. . (2006). Madrasah dan Pendidikan Anak Bangsa, Visi, Misi dan Aksi. Jakarta.: Raja Grafindo Persada.

Supani. (2009). Sejarah Perkembangan Madrasah di Indonesia. Jurnal Insania, 3,

Swasta. (1997). Potensi yang Butuh Pemberdayaan. Jurnal Madrasah, 1,

Terbuka. (1997). Baru Depag. Jurnal Madrasah, 1,

Tilar. (2000). Paradigma Baru Pendidikan Nasional. Jakarta: Rineka Cipta.

Umam. (2012). Kajian Empiris Terhadap Kebijakan dan Transformasi Madrasah pada Era Reformasi. Jurnal Edu-Islamika, 4,

Yahya, M. D. (2014). Posisi Madrasah Dalam Sistem Pendidikan Nasional Di Era Otonomi Daerah. Jurnal KHAZANAH, 1 , 